Bu makaleye atıfta bulunmak için/To cite this article:

ESRINGÜ, A. CANPOLAT, N. BARIŞ, Ö. (2021). "İklim Değișikliğinde Yeșil Adımlar" TÜBİTAK 4004 Proje

Değerlendirilmesi. Atatürk Üniversitesi Sosyal Bilimler Enstitüsü Dergisi, 25 (3), 883-902.

\title{
“İklim Değişikliğinde Yeşil Adımlar” TÜBİTAK 4004 Proje Değerlendirilmesi
}

\author{
Aslihan ESRING $\ddot{U}^{(*)}$ \\ Nurtaç CANPOLAT ${ }^{(* *)}$ \\ Özlem BARIŞ̧ ${ }^{(* * *)}$
}

Öz: Insan faaliyetleri sonucunda yerküreyi saran atmosferin bilesiminin bozulması nedeniyle yeryüzü slcaklığl ve hava olaylarında meydana gelen değişimler iklim değişikliği olarak ifade edilmektedir. İklim değişikliği ile hava sıcaklıklarında ve yağışlarda artışlar, çeşitli sağlık sorunları, biyoçeşitliliğin bozulmast, seller, yangınlar, göçler, habitat ve ekonomik kayıplar ortaya çıkarak yaşamı tehdit etmektedir. Bu problemler göz önünde bulundurulduğunda iklim değişikliğinin bütün insanlığın bir sorunu olduğu ve bütün insanların bu konuda duyarlı olması gerektiği anlaşılmaktadır. Bu kapsamda, ortaokul öğrencileri arasında iklim değişikliği ile ilgili farkındalı̆̆ın geliştirilmesi amacıla yürütülen ve TÜBITAK 4004 programı tarafindan desteklenen proje çalışmasında Erzurum iline bağlı İspir, Tortum ve Aşkale ilçelerindeki Yatılı Bölge Ortaokullarından (YBO) seçilen toplam 28 ögrenci ile 5 gün boyunca teorik ve uygulamalı dersler, gezi, gözlem vb. etkinlikler gerçekleştirilmiştir. Bu etkinlikler iklim değişikliğinin tanımı, nedenleri, etkileri ve alınabilecek bireysel ve toplumsal önlemler konularını kapsayacak şekilde tasarlanmıştır. Eğitimler ve diğer faaliyetler bu alanda uzman olan ögretim üyelerince yürütülmüş ve ögrencilere farkındalık kazandırılmaya çalışılmıştır. Sonuç olarak projede nitel ve nicel veri toplama araçlar ile elde edilen veriler neticesinde eğitime katılan ögrrencilerin iklim değişikliği konusunda farkındalıklarının iyileştiği tespit edilmiştir.

Anahtar Kelimeler: Ĕ̆itim, farkındalık, iklim değișikliği, ilköğretim öğrencisi, TÜBİTAK 4004-Doğa Ĕ̈itimi ve Bilim Okulları

\section{Evaluation of TUBITAK 4004 Project "Green Steps in Climate Change"}

Abstract: The changes in the earth's temperature and weather events due to the deterioration of the composition of the atmosphere surrounding the earth as a result of human activities are expressed as climate change. With climate change, increases in air temperatures and rainfall, various health problems, loss of biodiversity, floods, fires, migrations, habitat and economic losses pose a serious threat to life. When these problems are considered, it is understood that climate change is a problem of all humanity and all people should be sensitive about this issue. In the scope of the project supported by TÜBITTAK 4004 program to raise awareness about climate change among secondary school students totally 28 students selected from Regional

\footnotetext{
*) Doç. Dr., Atatürk Üniversitesi Mimarlık ve Tasarım Fakültesi Peyzaj Mimarlığı Bölümü, (eposta: esringua@atauni.edu.tr) (D) ORCID ID. https://orcid.org/0000-0002-7930-5290

$\left.{ }^{* *}\right)$ Prof. Dr., Atatürk Üniversitesi Kazım Karabekir Eğitim Fakültesi Matematik ve Fen Bilimleri Eğitimi Bölümü, (e-posta: nurtac@atauni.edu.tr) (D) ORCID ID. https://orcid.org/0000-00020295-4823

${ }^{* * * *}$ Prof. Dr., Atatürk Üniversitesi Fen Fakültesi Biyoloji Bölümü, (e-posta: baris@atauni.edu.tr) (D) ORCID ID. https://orcid.org/0000-0002-2679-5599.

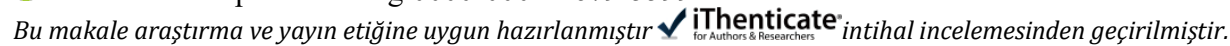


Boarding Secondary Schools in Ispir, Tortum and Aşkale districts of Erzurum attended theoretical and applied courses and trips and observation activities for 5 days. These activities were designed to involve educational activities on the definition, causes, effects and individual and social measures of climate change. Courses and other activities were conducted by expert faculty members and students gained awareness. As a result, it was determined from the data obtained through the qualitative and quantitative tools in the project that awareness and sensitivity increased about climate change among the students participating in the education.

Keywords: Education, awareness, climate change, elementary student, TÜBİTAK 4004Nature Education and Science School.

Makale Geliş Tarihi: 13.11.2020

Makale Kabul Tarihi: 15.09.2021

DOI: 10.53487/ataunisosbil.825275

\section{Giriș}

İklim değişikliği, günümüzde en önemli küresel sorunlardan biri olup insanların çeşitli faaliyetleri ile ilişkili olarak yerküreyi saran atmosfere salınan bazı gazların etkisiyle yeryüzü sıcaklığında ve hava olaylarında meydana gelen değişimleri kapsamaktadır. Bu şekilde değişikliğe neden olan gazlar sera gazları olarak adlandırılmaktadır. İnsan faaliyetleri neticesinde atmosferde bu gazların derişimlerinde önemli ölçüde artışlar ortaya çıkmakta ve buna bağlı olarak da küresel ısınma şeklinde de ifade edilen sıcaklık değişimleri oluşmaktadır. Sera gazları doğal olarak oluşmakta ancak insan faaliyetleri neticesinde bu gazların miktarında çok önemli artışlar meydana gelmektedir. Güneşten gelen ve yeryüzünden atmosfere yansiyan uzun dalga boylu ışınların bir bölümü, bulutlar ve atmosferdeki sera gazları (su buharı $\left(\mathrm{H}_{2} \mathrm{O}\right)$, karbondioksit $\left(\mathrm{CO}_{2}\right)$, metan $\left(\mathrm{CH}_{4}\right)$, diazotmonoksit $\left(\mathrm{N}_{2} \mathrm{O}\right)$, ozon $\left(\mathrm{O}_{3}\right)$, vb.) tarafından soğurulur. Sera etkisi normalde yeryüzü sıcaklık dengesi için gerekli bir mekanizmadır (MGM, 2020: 1). Ancak, fosil yakıtların yakılması, arazi kullanımı değişiklikleri, ormansızlaştırma, sanayi süreçleri gibi insan etkinlikleri, ekonomiler ve yaşam standartları büyüdükçe sera gazı (GHG) emisyonları da kümülatif olarak artmaktadır (EEA, 2020: 1) Bu durum da yer yüzünün ortalama sıcaklığının giderek artmasına yol açmaktadır.

Hükümetler arası İklim Değişikliği Paneli (IPCC)'nin 6'ıncı Değerlendirme Raporu 9 Ağustos 2021 de çevrim içi olarak yayınlandı. Raporda iklim değişikliğinin yaygın şekilde görüldüğü ve artarak hızla ilerlediği belirtilmektedir. İnsan kaynaklı iklim değişikliğinin şimdiden dünyanın her bölgesinde birçok aşırı hava ve iklim hareketine yol açarak ilerlediği ayrıca 1750 li yıllardan beri sera gazı (SG) konsantrasyonlarında gözlemlenen artışların kesinlikle insan faaliyetlerinden kaynaklandığı ifade edilmiştir. Bilim insanları, atmosfer, okyanuslar, denizler ve buzullar dahil olmak üzere Dünya'nın tüm iklim sistemlerinde değişiklikler gözlemlemişler. Son kırk yılın her biri, 1850'den bu yana önceki on yıldan daha sıcak olmuş şeklinde ifade kullanmışlardır. 21. yüzyılın ilk yirmi yılında (2001-2020) küresel yüzey sıcaklığ $1,1850-1900$ 'dan $0.99{ }^{\circ} \mathrm{C}$ daha 
yüksek olurken $2011-2020$ yıllarında $1850-1900$ 'dan $1,09{ }^{\circ} \mathrm{C}$ daha yüksek olduğu ve karada $\left(1,59^{\circ} \mathrm{C}\right)$ okyanusa göre daha büyük artışlar $\left(0,88^{\circ} \mathrm{C}\right)$ olduğu gözlemlenmiştir. Elde edilen veriler güncellenmiş 1 sınma tahminine yaklaşık $0,1^{\circ} \mathrm{C}$ katkıda bulunmuştur. Sanayi öncesi döneme göre küresel 1 sınma seviyelerindeki $1,5^{\circ} \mathrm{C}$ üzerindeki eşiğin aşılmasının "tehlikeli bir şekilde yakın olduğunu" belirtilerek yakın vadede $1,5^{\circ} \mathrm{C}$ dereceye ulaşma riskiyle karşı karşıya olduğumuz ve bu eşiğin aşılmasını önlemenin tek yolu acilen çabalarımızı hızlandırmak olduğu ifade edilmiştir. Ayrıca karalar üzerindeki küresel olarak ortalama yağışların 1950'den beri artış gösterdiği fakat 1980'lerden bu yana daha hızlı bir oranla arttığı belirtilmiştir (IPCC, 2021: 9).

İklim değişikliğine bağlı çevre faaliyetlerinin giderek artış gösterdiği günümüzde çevrenin korunması son derece önemli bir konudur ve bu konunun insanlara benimsetilmesi ancak eğitim ile kazandırılabilir. Özellikle çocuklara yönelik verilen çevre eğitimleri oldukça faydalı olmaktadır (González-Gaudiano ve Pablo Á. MeiraCartea, 2019: 398). İnsanlarda çevrenin korunmasına ilişkin bir sorumluluğun geliştirilmesinde çevre eğitimi krtik bir rol almaktadır (Varela-Candamio vd., 2018: 1573). Araştırmalarda doğada gerçekleştirilen çalışmalar yoluyla edinilen bilgilerin davranışa dönüşmesinin çok daha kolay olduğu ve bu şekilde öğrenilen bilgilerin daha kalıcı olduğu rapor edilmektedir (Oğurlu vd., 2013: 507). Ancak bu araştırmalarda ülkemizde doğa eğitimi üzerine yapılan projelerin yetersiz olduğu da belirtilmektedir. Son yıllarda yapılan bilim okullarına yönelik projelerde çocukların bilimsel bilgilerin günlük hayatla ilişkilerini öğrenebilmeleri ve çocukların bilimle uğraşmanın zevkli ve eğlenceli olduğunun farkına varmaları açısından faydalı olduğu dile getirilmektedir. Bu durum okul dışı öğrenme etkinliklerinin geliştirilmesine destek sağlanması açısından bilim okulları projelerinin önemli olduğunu göstermektedir (Tekbıyık vd., 2013: 1386). Yapılan araştırmalarda bilim okullarının/kamplarının öğrencilerin bilime karşı olumlu bir tutum geliştirmelerine katkı sağladığı (Akay, 2013: 335) ayrıca öğrencilere ilginç, farklı, faydalı ve eğlenerek öğrenme firsatı tanıdığı (Hırça, 2013: 28) ifade edilmektedir. Marulcu (2014: 341) tarafindan yapılmış bir çalışmada öğrencilerin büyük çoğunluğunun bilim okulunu eğlenceli bulduğu okulda yapamadıkları etkinlikleri yapabildikleri ve yapılan etkinliklerin okulda gördükleri dersleri günlük hayatla ilişkilendirmelerini sağladığını belirtmişlerdir. Ayrıca Avcı vd. (2015: 329) okul ortamı dışında gerçekleştirilen çalışmalardan öğrencilerin memnun kaldıklarını, eğlenerek öğrenmekten mutlu olduklarını, çevre bilinci ve davranışları konusunda olumlu yönde etkilendiklerini ifade etmişlerdir. Günümüzde artık geleneksel anlayışla öğrencilere bilgi aktarılması yerine öğrencilerin temel bilimsel olguları kavramalarının sağlanması, merak duygularının, araştırma ve öğrenme isteklerinin teşvik edilmesi önem arz etmektedir (Tekbıyık vd., 2013: 1385). Çevre eğitimleri, öğrencilerin görsel imgeleme gücünü desteklemesi, yeni bir bakış açısı kazandırarak yaratıcılıklarını, akademik başarılarını, öğretmen-öğrenci etkileşimini, hayal gücünü ve sosyal gelişimlerini desteklemektedir (Coyle, 2005: 53).

Tüm canlıları ve ekosistemi ilgilendiren iklim değişikliği gibi önemli bir konuda bireylerin bilinçli olup duyarlılık gösterebilmeleri için öncelikle bu konuda yeterince 
bilgi sahibi olmaları gerekmektedir. Dolayısıyla iklim değişikliği konusunda toplumun bütün kesimlerine yönelik eğitimler verilerek bireylerde konuyla ilgili farkındalık oluşturulması önemli görülmektedir. Bu nedenle yapılan çalışmada, farklı seviyelerdeki ortaokul öğrencilerine iklim değişikliği hakkında eğitimlerin verilmesi yoluyla onların küresel ısınmanın etkileri üzerine düşünmelerini ve konuyu kavramaları sağlanarak sürdürülebilir bir dünya için farkındalıklarının geliştirilmesi amaçlanmıştır. Çalışma TÜBİTAK 4004 projesi kapsamında yürütülmüştür.

Proje kapsamında yapılan etkinliklerle öğrencilerin merak duygularının geliştirilmesi, bilimsel bilgiye ulaşma isteklerinin harekete geçirilmesi ve böylece tüm canlılar için önem arz eden iklim değişikliği konusunda farkındalık ve duyarlılık oluşturulması hedeflenmiştir. Ayrıca eğitime katılan öğrencilerin okullarındaki diğer arkadaşlarına ve çevrelerindeki insanlara öğrendikleri bilgilerden bahsetmeleri, onlara örnek olmaları yoluyla çalışmanın çarpan etkisi oluşturup belirli bir düzeyde yaygın etkinin meydana getirilmesi düşünülmüştür. $\mathrm{Bu}$ hedeflerin gerçekleşmesi halinde çevreye karşı duyarlı ve doğa dostu bireylerin yetiştirilmesi hususunda proje kapsamında yapılan etkinliklerin katkı sağlayacağı değerlendirmesi yapılmaktadır.

\section{Yöntem}

Çalışmada nicel ve nitel araştırma süreçleri birlikte kullanılmıştır. Nicel kısımda katılımcı öğrencilerin iklim değişikliği ile ilgili konulardaki gelişimlerini ortaya koyabilmek amaciyla kontrol grupsuz ön test-son test deneysel desenden faydalanılmıştır (Karasar, 2006: 97). Çalışmada öğrencilere çeşitli etkinlikler yolu ile beş günlük bir eğitim verilmiştir. Etkinlikler öncesinde ve sonrasında iklim değişikliği farkındalık ölçeği uygulanarak öğrencilerin gelişim durumu incelenmeye çalışılmıştır. Nitel araştırma sürecinde ise yine etkinliklerden önce ve sonra konu ile ilgili kompozisyon yazdırılarak öğrencilerin konuyu içselleştirebilme düzeyleri değerlendirilmiştir. Bunların yanında eğitimler tamamlandıktan sonra öğrencilerin iklim değişikliği konusundaki bilgilerini ve eğitimlerle ilgili görüşlerini derinlemesine sorgulamak amacıyla yarı yapılandırılmış görüşmeler yapılmıştır. Eğitimler süresince çocukların gün boyunca yaptıkları etkinlikler ve öğrendikleri bilgiler üzerine düşünmelerini ve günü değerlendirmelerini sağlamak amacıyla da günlükler yazdırılmıştır.

\section{III. Çalışma Grubu}

Çalışma, ortaokul 6. ve 7. sınıfta öğrenim gören 13'ü kız, 15'i erkek olmak üzere toplam 28 öğrenci ile yürütülmüştür. Bu öğrenciler Erzurum ili Aşkale (9), İspir (9) ve Tortum (10) ilçelerindeki yatılı ilköğretim bölge okullarından rehber öğretmenlerin yardımı ve görüşleri ile seçilerek belirlenmiştir.

\section{Veri Toplama Araçları}

Projenin örnekleminde yer alan öğrencilerin iklim değişikliğine yönelik farkındalık düzeylerini ve bu konudaki gelişimlerini, eğitimlerle ilgili görüşlerini belirlemek 
amacıyla nitel ve nicel veri toplama araçları kullanılmıştır. Veri toplama aracı olarak, katılımcıların iklim değişikliği ile ilgili bilgi ve bilinç seviyelerini değerlendirmek üzere 15 soruluk bir farkındalık ölçeği ve bunun yanı sıra yarı yapılandırılmış görüşme, öğrencilere tutturulan günlükler ve yine öğrencilere yazdırılan kompozisyonlar kullanılmıştır. Atatürk Üniversitesi Sosyal ve Beşeri Bilimler Kurulu Başkanlığından Eğitim Bilimleri Birim Etik Kurulundan 11.10.2018 tarih ve No: 02 karar ile araştırmaların gerekçe, amaç, yaklaşım ve yöntemleri dikkate alınarak konuyla ilgili çalışmaların gerçekleştirilmesinde etik ve bilimsel yönden sakınca bulunmadığına dair izin belgesi alınmıştır.

\section{İklim değişikliği farkındalık ölçeği}

Proje kapsamındaki öğrencilerin iklim değişikliğine yönelik farkındalık düzeylerini belirleyebilmek için 15 soruluk bir farkındalık ölçeği hazırlanarak kullanılmıştır (Ek1). Ölçekte yer alan 15 adet önermenin 5'i olumlu, 10'u ise olumsuz olup "Katılıyorum", "Karasızım" ve "Katılmıyorum" seçeneklerini içerecek șekilde Likert olarak hazırlanmıştır. Bu ölçek oluşturulurken daha önce konu ile ilgili yapılmış olan çalışmalarda kullanılan ölçeklerden faydalanılmıştır (Pfautsch ve Gray, 2017: 1160; Tok vd., 2017: 27; Jaaskela vd., 2021: 794). Ölçek, öğrencilere eğitimden önce ve eğitimden sonra (ön test-son test) uygulanarak farkındalık düzeylerindeki gelişim belirlenmeye çalışılmıştır.

\section{Yarı yapılandırılmış görüşme formu}

Proje kapsamında öğrencilere yönelik etkinlikler gerçekleştirildikten sonra öğrencilerin iklim değişimi, iklim değişiminin nedenleri, iklim değişiminin etkileri ve iklim değişimi konusunda alınabilecek tedbirlere ilişkin görüşlerini ayrıntılı olarak alabilmek için etkinlikler sonrasında altı öğrenci (her okuldan 2 ögrenci) ile yarı yapılandırılmış görüşmeler yapılmıştır. Söz konusu görüşmeler için hazırlanan görüşme formunda aşağıdaki sorulara yer verilmiştir:

1- İklim değişikliği nedir? Kısaca bilgi verir misiniz?

2- İklim değişikliğinin nedenleri neler olabilir?

3- İklim değişikliğine yol açan başlıca gazlar hangileridir?

4- İklim değişikliğine yönelik, bireysel olarak ne tür tedbirler alınabilir?

5- İklim değişikliğine yönelik olarak devletler düzeyinde ne tür tedbirler alınabilir?

6- Projede yapılan etkinlikler hakkındaki görüşleriniz nelerdir?

\section{Günlükler}

Projede gerçekleştirilen eğitim süresince öğrencilerin dâhil oldukları etkinliklerin her birine yönelik olarak günlük tutmaları istenmiş ve bu günlüklerle proje kapsamındaki etkinliklerle ilgili olarak öğrencilerin görüşleri belirlenmiştir. 


$888 \begin{array}{lr}\text { Aslıhan ESRINGÜ } & \text { A T A S O B E D } \\ \text { Nurtaç CANPOLAT } & \text { Özlem BARIŞ }\end{array}$

\section{Kompozisyon}

Proje kapsamındaki öğrencilerden, etkinliklere başlamadan önce ve etkinlikler tamamlandıktan sonra; "İklim değişimi, iklim değişiminin nedenleri ve iklim değişimine yönelik olarak alınabilecek tedbirler" konularını kapsayacak şekilde bir kompozisyon yazmaları istenmiş ve öğrencilerin kompozisyonları yazarken kullandıkları terimler ve yazılarının içeriği değerlendirilerek iklim değişikliği konusundaki bilgilerinin gelişimi belirlenmeye çalışılmıştır.

\section{Verilerin Analizi}

Çalı̧smada nicel verileri analiz etmek amacıyla SPSS 20 paket programı kullanılmıştır. 15 maddelik "İklim değişikliği farkındalık ölçeği" kapsamındaki maddelere öğrencilerin verdikleri cevaplar olumlu önermelerde katılıyorum cevabı 3, karasızım 2 ve katılmıorum 1 puan, olumsuz önermelerde ise tersi puanlama yapılmıştır. Bu ölçeğin ön test ve son test puan ortalamaları arasında istatistiksel olarak anlamlı bir farkın bulunup bulunmadı̆̆ını görebilmek üzere eşleştirilmiş grup t-testi uygulanmıştır. Öğrenciler ile yapılan yarı yapılandırılmış görüşmeler ve onların kompozisyonları ile günlükleri ise nitel olarak analiz edilip değerlendirilmiş̧ir. Öğrencilerin kompozisyonları değerlendirilirken öncelikle her bir öğrencinin kompozisyonları kapsam açısından incelenmiş ve ne kadar cümle kurabildikleri analiz edilmiştir. Ayrıca kompozisyonların içeriği değerlendirilmeye çalışılmıştır. Yarı yapılandırılmış görüşmelerde öğrencilere sorulan temel sorulara ve bu sorular kapsamındaki alt sorulara verilen cevaplar analiz edilerek cevapların frekansları belirlenmiştir. Günlüklerin analizinde ise her okuldan iki öğrencinin günlükleri analiz edilerek hangi etkinliklerin öğrencilerde iz bıraktığı ve kalıcı olduğu belirlenmeye çalışılmıştır.

\section{Uygulama Süreci}

10.06.2019-15.06.2019 tarihleri arasında TÜBİTAK 4004 Doğa Eğitimi ve Bilim Okulları çağrısı kapsamında desteklenen "İklim Değişikliğinde Yeşil Adımlar" projesi Erzurum'da gerçekleştirilmiştir. Proje kapsamında verilen eğitimler ile öğrencilerin iklim değişikliği konusunda bilinçlenmeleri, ulusal ve küresel seviyelerde yapılacak çalışmalar ve alınabilecek önlemler hakkında bilgi sahibi olmaları ve böylece karşılaşacakları çevresel problemlere karşı arzu edilen farkındalıkları geliştirmeleri amaçlanmıştır. Eğitim kısmı 5 gün olarak planlanan projede alanında uzman akademisyenler tarafindan deneysel, gözlemsel, hesaplamalı bilim ve oyun tabanlı uygulamalar gerçekleştirilmiştir. $\mathrm{Bu}$ uygulamalarla bilgilerin mümkün olduğunca hayatla ilişkilendirilip görselleştirilerek sunulması hedeflenmiştir.

Proje kapsamında öğrencilere yönelik olarak yapılan tüm faaliyet ve etkinlikler Tablo 1' de verilmişsir. Etkinlikler;

- İklim elemanları 
"İklim Değișikliğinde Yeșil Adımlar" TÜBİTAK 4004 Proje

Değerlendirilmesi

- Küresel iklim değişikliğinin nedenleri,

- İklim değişikliğine yönelik bireysel ve toplumsal alınabilecek önlemler

- Türkiye ve dünyanın iklim değişikliğinden etkilenme durumu

- Karbon ayak izi

- Karbon ayak izinin azaltılmas1

- Doğa ve çevreyi koruma

gibi konularda alanında uzman öğretim üyeleri tarafından uygulamalı olarak gerçekleştirilmiştir. Ayrıca katılımcıların, kamp kapsamı içinde yaratıcı drama yöntemiyle tanışma, kaynaşma, iletişim, kendini ifade etme, merak, farkındalık ve keşfetme gibi becerilerini geliştirmek amacıyla yine alanında uzman bir öğretim üyesi tarafından çeşitli etkinlikler yaptırılmıştır.

Tablo 1. Etkinlik Günleri ve İsimleri

\begin{tabular}{|c|c|c|c|}
\hline Günler & Etkinlik Adı / Faaliyet & Günler & Etkinlik Adı / Faaliyet \\
\hline 1.Gün & $\begin{array}{l}\text { Açılış Töreni } \\
\text { Tanışma Zamanı } \\
\text { Takım Ruhu } \\
\text { Merhaba İklim Elemanları } \\
\text { Şehrimi Tanıyorum } \\
\text { Günce Yazma }\end{array}$ & 3.Gün & $\begin{array}{l}\text { Süper Kahramanlar } 1 \\
\text { Süper Kahramanlar } 2 \\
\text { İklim Değişince Ne Olur? } \\
\text { Gökkuşağı Kartları } \\
\text { Soğuk Ama Eğlenceli } \\
\text { Günce Yazma }\end{array}$ \\
\hline 2.Gün & $\begin{array}{l}\text { Suçlu Kim? } \\
\text { Örtü Altında Gezinti } \\
\text { Yeşil Serüven } 1 \\
\text { Yeşil Serüven } 2 \\
\text { Geleceğe } 1 \text { Fidan } \\
\text { Günce Yazma }\end{array}$ & 4.Gün & $\begin{array}{l}\text { Karbon Ayak İzimi Hesaplıyorum } \\
\text { Kara Tehlike } \\
\text { Temiz Enerji } 1 \\
\text { Temiz Enerji } 2 \\
\text { Gelecek için Üniversite } \\
\text { Günce Yazma }\end{array}$ \\
\hline 5.Gün & $\begin{array}{l}\text { Ben Çöp Değilim } 1 \\
\text { Ben Çöp Değilim } 2 \\
\text { Tehlikenin Neresindeyiz1? } \\
\text { Tehlikenin Neresindeyiz2? } \\
\text { Sevgi Bombardımanı } \\
\text { Günce Yazımı }\end{array}$ & 6. Gün & $\begin{array}{l}\text { Kapanış } \\
\text { Son Test } \\
\text { Değerlendirme }\end{array}$ \\
\hline
\end{tabular}




\section{Bulgular}

“İklim Değişikliğinde Yeşil Adımlar” projesi kapsamında veriler nicel ve nitel olarak toplanmış ve analiz edilmiştir.

$\mathrm{Bu}$ çalışmada etkinlikler öncesinde ve sonrasında 15 sorudan oluşan iklim değişikliği farkındalık ölçeği öğrencilere ön test ve son test olarak uygulanmış ve ögrencilerin bu ölçekten almış olduğu puanlar Tablo 2'de verilmiştir.

Tablo 2. Öğrencilerin Ön Test - Son Test Puanları

\begin{tabular}{|l|l|l|l|l|l|}
\hline Ö̆̆renci & Ön test & Son test & Ö̆̆renci & Ön test & Son test \\
\hline $\mathbf{1}$ & 41 & 41 & $\mathbf{1 5}$ & 39 & 42 \\
\hline $\mathbf{2}$ & 39 & 43 & $\mathbf{1 6}$ & 35 & 43 \\
\hline $\mathbf{3}$ & 37 & 42 & $\mathbf{1 7}$ & 34 & 41 \\
\hline $\mathbf{4}$ & 37 & 41 & $\mathbf{1 8}$ & 36 & 41 \\
\hline $\mathbf{5}$ & 40 & 38 & $\mathbf{1 9}$ & 43 & 41 \\
\hline $\mathbf{6}$ & 36 & 42 & $\mathbf{2 0}$ & 35 & 34 \\
\hline $\mathbf{7}$ & 39 & 43 & $\mathbf{2 1}$ & 38 & 34 \\
\hline $\mathbf{8}$ & 39 & 45 & $\mathbf{2 2}$ & 30 & 36 \\
\hline $\mathbf{9}$ & 39 & 43 & $\mathbf{2 3}$ & 38 & 41 \\
\hline $\mathbf{1 0}$ & 38 & 43 & $\mathbf{2 4}$ & 41 & 43 \\
\hline $\mathbf{1 1}$ & 42 & 45 & $\mathbf{2 5}$ & 32 & 39 \\
\hline $\mathbf{1 2}$ & 39 & 43 & $\mathbf{2 6}$ & 38 & 45 \\
\hline $\mathbf{1 3}$ & 40 & 43 & $\mathbf{2 7}$ & 41 & 43 \\
\hline $\mathbf{1 4}$ & 36 & 45 & $\mathbf{2 8}$ & 29 & 42 \\
\hline
\end{tabular}

Tablo 2'den de görüldüğü gibi öğrencilerin oldukça önemli bir k1smı iklim değişikliği farkındalık ölçeğinden son testte ön teste göre daha yüksek puan almışlardır. $\mathrm{Bu}$ durum yapılan etkinliklerin öğrencilerin iklim değişikliği hakkındaki farkındalıklarını geliştirdiğini göstermektedir.

Öğrencilerin iklim değişikliğine yönelik farkındalık düzeylerinde meydana gelen değişimin istatistiksel olarak anlamlı olup olmadığını belirlemek amacı ile eşleştirilmiş grup t testi yapılmış ve sonuçları Tablo 3 'te verilmiştir.

Tablo 3. Eşleştirilmiş Grup t-Testi Sonuçları

\begin{tabular}{|l|l|l|l|l|l|}
\hline & $\mathbf{N}$ & $\overline{\boldsymbol{X}}$ & $\mathbf{s s}$ & $\mathbf{t}$ & $\mathbf{p}$ \\
\hline Ön test & 28 & 37,5357 & 3,36080 & $-5,802$ & 0.000 \\
\hline
\end{tabular}


“íklim Değişikliğinde Yeșil Adımlar" TÜBITTAK 4004 Proje Değerlendirilmesi

\begin{tabular}{|l|l|l|l|l|l|}
\hline Son test & 28 & 41,5000 & 2,93762 & & \\
\hline
\end{tabular}

Öğrencilerin iklim değişikliği farkındalık ölçeği ön test ortalamasının 37,5357 son test ortalamasının ise 41,5000 olduğu Tablo 3'den görülmektedir. Yine bu tablodaki bulgular ön test ve son test arasındaki ortalama farkının istatistiksel açıdan anlamlı olduğunu ortaya koymaktadır $(t=-5.802 ; p<.05)$. Testten alınabilecek maksimum puanın 45 olduğu düşünüldüğünde son test ortalaması $(41,5000)$, iklim değişikliği konusunda öğrencilerin oldukça iyi bir duruma geldiklerini göstermektedir.

Ön test ve son test olarak uygulanan iklim değişikliği farkındalık ölçeğindeki her bir maddeden alınan ortalama puanlar hesaplanarak Tablo 4 'te verilmiştir.

Tablo 4. İklim Değişikliği Farkındalık Ölçeği Maddelerinden Alınan Ortalama Puanlar

\begin{tabular}{|l|l|l|}
\hline Madde & Ön test & Son test \\
\hline 1 & 2,75 & 3,00 \\
\hline 2 & 2,18 & 2,89 \\
\hline 3 & 2,79 & 2,93 \\
\hline 4 & 2,86 & 2,93 \\
\hline 5 & 2,57 & 2,68 \\
\hline 6 & 2,11 & 2,96 \\
\hline 7 & 2,54 & 2,79 \\
\hline 8 & 2,36 & 2,82 \\
\hline 9 & 1,79 & 1,64 \\
\hline 10 & 2,82 & 2,93 \\
\hline 11 & 2,71 & 2,86 \\
\hline 12 & 2,07 & 2,21 \\
\hline 13 & 2,79 & 2,96 \\
\hline 14 & 2,79 & \\
\hline
\end{tabular}




\begin{tabular}{|l|l|l|}
\hline 15 & 2,43 & 2,93 \\
\hline
\end{tabular}

Tablo 4'deki verilerden 9. madde dışındaki maddelerin tamamında son testteki ortalama puanın ön testtekinden daha yüksek olduğu anlaşılmaktadır. Yani son testte bu maddelerin doğru cevaplanma oranlarında dikkate değer bir artış olmuştur. $\mathrm{Bu}$ durum öğrencilerin iklim değişikliği konusundaki farkındalıklarında önemli bir değişimin olduğunu ve proje kapsamında yapılan etkinliklerin faydalı olduğunu açıkça ortaya koymaktadır.

Proje kapsamında yer alan öğrencilerin iklim değişikliği konusundaki farkındalık ve anlayışlarında yapılan eğitim eşliğinde bir gelişmenin olup olmadığını değerlendirebilmek amacıyla 15 maddeden oluşan ölçek yanında öğrencilere eğitim öncesinde ve sonrasında kompozisyon yazdırılmıştır. Öğrencilerin eğitimler öncesinde ve sonrasında kompozisyonlarında oluşturabildikleri yaklaşık cümle sayıları Tablo 5 'te verilmiştir.

Tablo 5. Öğrencilerin Kompozisyonlarındaki Cümle Sayıları

\begin{tabular}{|l|l|l|l|l|l|}
\hline Öğrenci & $\begin{array}{l}\text { Etkinlik } \\
\text { Öncesi }\end{array}$ & $\begin{array}{l}\text { Etkinlik } \\
\text { Sonrası }\end{array}$ & Öğrenci & $\begin{array}{l}\text { Etkinlik } \\
\text { Öncesi }\end{array}$ & $\begin{array}{l}\text { Etkinlik } \\
\text { Sonrası }\end{array}$ \\
\hline 1 & 12 & 39 & 15 & 11 & 11 \\
\hline 2 & 6 & 11 & 16 & 13 & 33 \\
\hline 3 & 6 & 15 & 17 & 13 & 8 \\
\hline 4 & 5 & 15 & 18 & 14 & 9 \\
\hline 5 & 7 & 17 & 19 & 12 & 16 \\
\hline 6 & 9 & 13 & 20 & 5 & 6 \\
\hline 7 & 7 & 7 & 21 & 9 & 13 \\
\hline 8 & 6 & 19 & 22 & 6 & 6 \\
\hline 9 & 11 & 10 & 23 & 5 & 8 \\
\hline 10 & 11 & 6 & 24 & 9 & 8 \\
\hline 11 & 16 & 21 & 25 & 9 & 8 \\
\hline
\end{tabular}


“íklim Değişikliğinde Yeșil Adımlar" TÜBITTAK 4004 Proje Değerlendirilmesi

\begin{tabular}{|l|l|l|l|l|l|}
\hline 12 & 12 & 12 & 26 & 13 & 18 \\
\hline 13 & 10 & 10 & 27 & 12 & 9 \\
\hline 14 & 14 & 10 & 28 & 8 & 23 \\
\hline
\end{tabular}

Tablo 5 incelendiğinde eğitim sonrasında yazılan kompozisyonlarda 15 öğrencinin cümle sayılarını artırdığı 7 öğrencinin cümle sayısının aynı kaldığı 6 öğrencinin ise cümle sayısında azalma olduğu görülmektedir. Yani öğrencilerin önemli bir kısmı proje kapsamında yapılan etkinlikler sonrasında daha kapsamlı kompozisyon oluşturabilmişlerdir.

Kompozisyonların analizinden küresel ısınma ve iklim değişikliğinin önüne geçilebilmesi için alınabilecek önlemlerle ilgili öğrencilerin çok çeşitli görüşlerinin olduğu görülmektedir. Bu görüşler Tablo 6' da verilmiştir.

Tablo 6. Öğrencilere Göre İklim Değişikliğine Yönelik Alınabilecek Önlemler

\begin{tabular}{|l|l|l|}
\hline \multirow{2}{*}{ Önlem } & \multicolumn{2}{l|}{ Frekans } \\
\cline { 2 - 4 } & $\begin{array}{l}\text { Etkinlikler } \\
\text { Öncesi }\end{array}$ & $\begin{array}{l}\text { Etkinlikler } \\
\text { Sonrası }\end{array}$ \\
\hline Ağaç dikmek & 4 & 20 \\
\hline Ağaçlar kesilmemeli & 2 & 2 \\
\hline $\begin{array}{l}\text { Orman yangınları engellenmeli, ormanlara } \\
\text { verilmemeli }\end{array}$ & 3 & - \\
\hline $\begin{array}{l}\text { Fosil yakıtlar azaltılmalı, fabrika-araba gazları azaltılmalı } \\
\text { (filtre takılmalı) }\end{array}$ & 8 & 17 \\
\hline Yenilenebilir enerji kaynakları kullanılmalı & 2 & 13 \\
\hline Yerlere çöp atılmamalı & 4 & 9 \\
\hline Çöpler ayırılmalı ve geri dönüşüm yapılmalı & 2 & 9 \\
\hline Çevreye zarar verilmemeli & 5 & 4 \\
\hline Toplu taşıma kullanılmalı & 4 & 7 \\
\hline
\end{tabular}


Aslihan ESRINGÜ

\begin{tabular}{|l|l|l|}
\hline Bisiklet kullanılmalı ya da yürünmeli & 1 & 6 \\
\hline Elektrikli arabalar kullanılmalı & 1 & 1 \\
\hline Deodorant-parfüm kullanımı azaltılmalı & 8 & 1 \\
\hline Karbon ayak izi küçültülmeli & - & 4 \\
\hline Tasarruflu ev eşyaları (elektrikli ev eşyaları) kullanılmalı & - & 5 \\
\hline İhtiyaç ve istekler karıştırılmamalı & - & 6 \\
\hline Tasarruf (her türlü tasarruf) yapılmalı & 2 & 10 \\
\hline Isı yalıtımı yapılmalı & - & 1 \\
\hline Büyükbaş hayvan eti tüketilmemeli & - & 1 \\
\hline
\end{tabular}

Tablo 6'dan da görülebileceği gibi öğrencilerin iklim değişikliği ya da küresel 1sınmaya yönelik olarak dile getirdikleri önlemler oldukça çeşitlidir. Etkinlikler öncesinde yazılan kompozisyonlarda belirtilen önlemler arasında; "Fosil yakitlar azaltılmalı, fabrika-araba gazları azaltılmalı (filtre takılmalı)" ve "Deodorant-parfüm kullanımı azaltılmalı" önlemleri dikkat çekmektedir. Etkinlikler sonrasında ise; "Ağaç dikmek", "Fosil yakıtlar azaltılmalı, fabrika-araba gazları azaltılmalı (filtre takılmalı)", "Yenilenebilir enerji kaynakları kullanılmalı", "Yerlere çöp atılmamalı", "Çöpler ayırılmalı ve geri dönüşüm yapılmalı" "Toplu taşıma kullanılmalı" ve "Tasarruf yapılmalı" gibi önlemlerin yaygınlığının fazla olduğu görülmektedir.

$\mathrm{Bu}$ projede etkinlikler tamamlandıktan sonra öğrencileri iklim değişikliği konusundaki bilgilerini daha ayrıntılı bir şekilde belirleyebilmek amacıyla altı öğrenci ile yarı yapılandırılmış mülakat yapılmış ve elde edilen bulgular Tablo 7'de verilmiştir.

Tablo 7. Yarı Yapılandırılmış Mülakat Bulguları

\begin{tabular}{llc}
\hline \multicolumn{1}{c}{ Soru } & Cevap & Frekans \\
\hline $\begin{array}{l}\text { 1-İklim değişikliği nedir? } \\
\text { Kisaca bilgi verir misiniz? }\end{array}$ & $\bullet$ Isınmanın olması & 5 \\
$\begin{array}{l}2-\quad \text { İklim değişikliğinin } \\
\text { nedenleri neler olabilir? }\end{array}$ & $\bullet$ Çöpler & 2 \\
& $\bullet$ Fosil yakıtların kullanılması & 2 \\
& $\bullet$ Doğal gaz kullanımı & 1
\end{tabular}


“íklim Değişikliğinde Yeşil Adımlar" TÜBİTAK 4004 Proje Değerlendirilmesi

- Sera gazları

- Eksoz gazları

- İsraf

3-İklim değişikliğine yol • Karbondioksit 6

açan başlica gazlar nelerdir? Metan 6

- Doğal gaz

- Karbonmonoksit 2

- Azot gazları 1

- Klorofloro karbon

4- İklim değişikliğine • Yerlere çöp atmamak 1

yönelik bireysel olarak ne tür • Yenilenebilir enerji kaynaklarından faydalanmak 2

tedbirler alınabilir?

- Tasarruf etmek (boşa enerji kullanmamak)

- Toplu taşımanın kullanılması

- Araç yerine yürünebilir 3

• Geri dönüşüme önem verilmesi 3

- Ağaç dikmek

5- İklim değişikliğine • Fosil kökenli yakıt kullanımının yasaklanması

yönelik olarak devletler nasıl • Yenilenebilir enerji kaynaklarının kullanılması

tedbirler alabilir? $\quad$ - Yenilenebilir enerji kaynakıannın kullanılması

- Yerler çöp atılmasına ceza verilmeli 3

- Çevre eğitimi verilmeli 2

- Ağaç dikmek 2

- Toplu taşımaya önem verilmesi 1

- Spor, yürüyüs ve bisikletin teşvik edilmesi

6- Projede yapılan eğitimler • Yeni şeyler öğrendim 2

$\begin{array}{lll}\begin{array}{l}\text { hakkındaki } \\ \text { nelerdir? }\end{array} & \text { görüşleriniz } & \text { - Ağaçların faydalarını öğrendim }\end{array}$

$\begin{array}{ll}\text { nelerdir? } & \text { Ağaçların faydalarını öğrendim } \\ & \text { • Fosil yakıtların zararlarını öğrendim }\end{array}$

- İklim değişikliğine yönelik tedbir alınması konusunda 1 faydalı oldu

- Sera gazlarını öğrendim 
- Çevre ile ilgili bilgilerimiz arttı 1

- Çevre duyarlılığı kazandık 1

- Önlem alınmazsa neler olacağını öğrendik 1

- Eğitimler güzeldi 1

- Yanlış bildiklerimizi düzelttik 1

- Teorik kisimlar kısaltılip uygulamalar daha fazla yer 1 verilmeli

- Bu eğitimler bütün okullarda olmalı

- Eğlendik 1

Tablo 7'den öğrencilerin önemli bir kısmının iklim değişikliğini 1sınma yani ortalama sıcaklığın artması (küresel ısınma) şeklinde düşündükleri ve mülakata katılan öğrencilerin tamamı küresel ısınma ve iklim değişikliğine neden olan gazlar arasında karbondioksit ve metanı saydıkları ve bu gazların da özellikle fosil kökenli yakıtlardan kaynaklandığını dile getirdikleri görülmektedir. Ancak, mülakat sırasında öğrencilere yöneltilen ek sorulara verilen cevaplarda üç öğrencinin (Ö3, Ö7 ve Ö23) küresel 1sınmayı ozon tabakasındaki tahribatla ilişkilendirdikleri anlaşılmıştır. Öğrencilerin cevaplarından alıntılar aşağıdaki gibidir:

"Çöplerden karbondioksit ve metan gazları oluşur. Bunlarda ozon tabakasını incelterek ısınmaya sebep olur. ” (Ö3)

“Ozon tabakasının delinmesi ve sera gazlarının etkisi ile ısınma” (Ö7)

"Sera gazları ve ozon tabakasının incelmesi..." (Ö23)

Mülakatlardaki ilave sorular üzerine öğrencilerin yapmış oldukları açıklamalardan, mekanizmasını tam olarak açıklayamasalar da öğrencilerin iklim değişikliğini ağırlıklı olarak fosil kökenli yakıtlarla ilişkilendirdikleri ve yenilenebilir enerji kaynaklarının önemini vurguladıkları anlaşılmaktadır. Bazı öğrenciler ise ısınmanın mekanizmasını güneş 1şınlarının bir kısmının atmosferde tutularak 1sınmaya yol açtığını çizdikleri şekillerle rahatlıkla açıklayabilmektedirler.

Küresel 1sınma ve iklim değişikliğine yönelik olarak alınabilecek tedbirleri dile getirirken öğrencilerin ağırlıklı bir şekilde ağaç dikme etkinliklerine önem verilmesi gerektiğine dikkat çekmeleri oldukça önemli bir bulgu olarak düşünülmektedir. Bunların yanı sıra mülakatlardan öğrencilerin; fosil yakıtların mutlaka azaltılması, yenilenebilir enerji kaynaklarına önem verilmesi ve tasarruf yapılması gerektiğini vurguladıkları anlaşılmaktadır. Yine öğrenciler bireysel olarak alınabilecek önlemlerin yanı sıra devletlerinde bu yönde önlemler alması gerektiğini ifade etmektedirler. 
Ayrıca, öğrenciler yapılan etkinliklerden çok memnun kaldıklarını, bunları faydalı bulduklarını ve tekrar yapılması halinde bu tür etkinliklere mutlaka katılacaklarını vurgulamışlardır. Mülakata katılan öğrenciler yapılan etkinliklere yönelik önemli görülebilecek herhangi bir olumsuz görüş dile getirmemişlerdir. Sadece bir öğrenci teorik kısmın biraz azaltılarak grup çalışmalarına daha fazla ağırlık verilmesinin iyi olabileceğini önermiştir. Öğrenciler, bu eğitimlerin aslında bütün okullarda gerçekleştirilmesinin çok faydalı olacağını da ifade etmişlerdir.

Öğrencilere yazdırılan günlükler incelenerek her okuldan iki öğrencinin günlükleri ayrıntılı olarak analiz edilmiştir. Günlüklerde öğrencilerin gün boyunca yapılan etkinlikleri özetledikleri, genellikle etkinlikler yoluyla öğrendikleri bilgilere yer verdikleri görülmüştür. Bu günlüklerde öğrenciler özellikle Erzurum Meteoroloji İl Müdürlüğü (Radyazonde balonu atılması), ATA Botanik Bahçesi, Atatürk Üniversitesi (AÜ) Su Ürünleri Fakültesi Alabalık Üretim Tesisleri, AÜ güneş panellerine yapılan geziler ve ağaç dikme, çöp toplama etkinliklerine yer vererek faaliyetler hakkında memnuniyetlerini dile getirmişlerdir.

\section{Sonuç ve Tartışma}

Öğrencilerin iklim değişikliği ve küresel 1sınma konusundaki farkındalık düzeylerinin iyileştirilmesinin ve sürdürülebilir bir dünya için gerekli tutum ve davranış değişikliklerinin teşvik edilmesinin amaçlandığı bu çalışma kapsamında yapılan etkinlikler sonrasında elde edilen bulgulardan öğrencilerin;

- Farkındalık düzeylerinin önemli ölçüde geliştiği,

- Küresel ısınma ve iklim değişikliğinin nedenlerini kavradıkları,

- $\quad \mathrm{Bu}$ konuda bireyler ve devletler tarafından alınabilecek önlemler ile ilgili farkındalık oluştuğu,

- Küresel ısınma ve iklim değişikliği konusunda duyarlılığın önemini kavradıkları,

- Yapılan eğitimlerle ilgili olarak olumlu görüşlere sahip oldukları,

- Eğitimlere rağmen bazı eksiklik ve yanlışlarının hala var olduğu gibi sonuçlar çıkarılabilir.

Tablo 2, Tablo 3 ve Tablo 4'te yer alan bulgular öğrencilerin iklim değişikliği ve küresel ısınma konusundaki gelişimi açıkça ortaya koymaktadır. Öğrencilerin büyük çoğunluğunun iklim değişikliği tutum ölçeğinden son testte almış oldukları puanlar ön testten almış oldukları puanlardan daha yüksek olmuştur (Tablo 2). Bunun sonucu olarak son test puan ortalaması ön test puan ortalamasından daha yüksek olmuştur (Tablo 3). Ayrıca bu puan farkının istatistiksel olarak anlamlı olduğu da yine Tablo 3'ten anlaşılmaktadır. Diğer taraftan bir madde dışında (9. madde) bütün maddelerden alınan ortalama puanların son testte daha yüksek olduğunu Tablo 4 ortaya koymaktadır. 
Bu madde, "İklim değişikliği ozon tabakasındaki incelmeden kaynaklanır" şeklindedir. Bu bulgular öğrencilerin, ozon tabakasının işlevi ile küresel ısınma ve dolayısıyla iklim değişikliği arasında bir ilişkinin mevcut olduğunu düşündükleri anlaşılmaktadır. İklim değişikliği farkındalık ölçeğine verilen cevaplardan tespit edilen "İklim değişikliği ozon tabakasındaki incelmeden kaynaklanır" şeklindeki yanlış anlayışın kompozisyonlarda da dile getirildiği görülmektedir. Öğrenciler kompozisyonlarında genellikle ozon tabakası incelmesi veya delinmesinin küresel 1sınmaya yol açtığını belirtmektedir. $\mathrm{Bu}$ durum yanılgının öğrencilerin zihinlerinde yer ettiğini ortaya koymaktadır. Eğitimlerden önce yazdırılan kompozisyonlarda 11 öğrenci bu yanlış anlayışa yer verirken eğitimlerin sonunda yazdırılan kompozisyonlarda 5 öğrencinin ozon tabakasının incelmesinin küresel ısınmaya yol açtığını belirttikleri görülmektedir.

Eğitimler öncesinde ozon tabakasının zarar görmesi ile küresel ısınmayı doğrudan ifade eden öğrencilerin yanı sıra bazı öğrencilerde (4 öğrenci) doğrudan ozon tabakasını ifade etmeden insanların kullanmış oldukları parfüm ve deodorantlardan bahsederek dolaylı bir şekilde yine ozon tabakasını işaret etmişlerdir. Ancak bu durum öğrencilerin iklim değişikliği farkındalık ölçeği son testinde vermiş oldukları cevaplarla (Tablo 3; 9. madde) çelişiyor gibi görünmektedir. Bu durumun öğrencilerin eğitimlerde sera gazlarını ve sera etkisini öğrenmelerinden kaynaklandığı düşünülmektedir. Öğrenciler bu bilgileri öğrendikleri için küresel 1sınmayı ozon tabakası ile ilgili önceki bilgilerine ihtiyaç duymadan sera etkisi ile açıklamaktadırlar. Ancak yazılı ya da sözlü ifade dışında öğrenciler gördüğünü seçme konusunda yine eski yanlış bilgilerini kullanmaya devam ettikleri anlaşılmaktadır. Buna rağmen öğrencilerin eğitimlerde küresel ısınmanın nedeninin ne olduğunu anladıkları ve sözlü ya da yazılı açıklamalarında doğru bilgileriyle açıklama yapabilecekleri söylenebilir. Öğrencilerin eğitimlerden sonra yazmış oldukları kompozisyonlarda bu durum açıkça görülmektedir. Eğitimler öncesinde yazılan kompozisyonlarda küresel 1sınmanın nedeni olarak önemli ölçüde ozon tabakasının zarar görmesi ve küresel ısınmanın ozon tabakası ile ilişskilendirilerek açıklanmasına rağmen eğitimlerin sonrasında oluşturulan kompozisyonlarda ağırlıklı bir şekilde sera gazlarına dikkat çekilmiş ve küresel ısınma sera etkisi ile açıklanmıştır.

“Ülke olarak bizim gerekli tedbirleri almamız, Türkiye’yi iklim değişimine karşı koruma açısından yeterli olacaktır." şeklindeki 12. madde de ise doğru cevaplanma oranı diğerlerine göre kısmen düşük olmuştur. $\mathrm{Bu}$ maddenin doğru cevaplanma oranının düşük olması da öğrencilerin iklim değişikliğinin küresel bir olgu olduğunu tam olarak kavrayamadıklarını göstermektedir. 9 ve 12. maddelerin dışındaki maddelerde hem son test cevap oranlarında anlamlı bir artış olmuş hem de doğru cevap oranları yüksek olmuştur. Bütün bunlar eğitimin iklim değişikliği ve küresel 1sınma konusunda çok önemli bir gelişime yol açtığını göstermektedir. Çalışma kapsamında elde edilen nitel bulgular da bu sonuçları destekler mahiyettedir. Tablo 6'dan da anlaşılacağı üzere kompozisyonlarda öğrencilerin önemli bir kısmının etkinliklerden sonra daha ayrıntılı açıklamalar yaparken bazı öğrencilerin ise kurdukları cümle sayısı etkinliklerden önce oluşturdukları kompozisyonlarla aynı kalmıştır. Bazı öğrencilerin 
de kompozisyonlardaki cümle sayısı azalmasına rağmen kurdukları cümlelerin çok daha anlamlı ve konuyu daha doğru bir şekilde açıklar nitelikte olduğu söylenebilir. Kompozisyon bulguları etkinlikler sonrasında öğrencilerin iklim değişikliği ile ilgili konularda söyleyebilecekleri daha çok şeyin bulunduğu, bilgi ve farkındalıklarının iyileştiği sonucunu ortaya koymaktadır. Cümle sayılarında azalma olan öğrencilerin bazılarının farkındalık ölçeğinden oldukça yüksek puan aldıkları Tablo 1'den anlaşılmaktadır. Bu durum öğrencilerin kompozisyon yazma sırasında ya ciddiyetsiz davrandıkları ya da yazma becerilerinin iyi olmadığı şeklinde değerlendirilebilir. Örneğin 14 numaralı öğrenci farkındalık ölçeğinden tam puan almış olduğu halde kompozisyonda yazabildiği cümle sayısında azalma olmuştur. Yine 10 ve 27 numaralı öğrenciler farkındalık ölçeğinden 45 puan üzerinden 43 puan alarak iyi bir başarı sergilemelerine rağmen kompozisyonlarında cümle sayısının azaldığ görülmektedir. Oluşturulan kompozisyonlarda içerik açısından değerlendirme yapıldığında eğitimlerin sonunda yazılan kompozisyonlarda öğrencilerin iklim değişikliği konusunda daha anlamlı cümleler kurdukları açıkça görülebilmektedir. Eğitim öncesi ve sonrasında oluşturulan kompozisyonlarda yaklaşık olarak aynı sayıda cümle ile oluşturulan kompozisyonlarda hatta cümle sayısının azaldığı durumlarda da eğitim sonrası yazılan metinlerde kullanılan cümlelerin iklim değişikliği ile ilgili olduğu anlaşılmaktadır. Eğitim öncesinde yazılan kompozisyonlarda konuyla ilgili olmayan rasgele yazılmış cümlelerin sayısının daha fazla olduğu söylenebilir.

İklim değişikliği ve küresel 1sınmaya yönelik olarak alınabilecek önlemler hususunda etkinlikler sonrasındaki kompozisyonlarda etkinliklerden önceki kompozisyonlara göre daha fazla çeşitlilik olduğu ve bu önlemlere daha fazla vurgu yapıldığı görülmektedir. Tablo 6'ya göre etkinlikler sonrasında oluşturulan kompozisyonlarda alınabilecek önlemlerdeki çeşitliliğin ve genel olarak yaygınlık düzeyinin daha fazla olduğu söylenebilir. Sadece "Deodorant-parfüm kullanımı azaltılmalı" şeklindeki önlemin yaygınlığının etkinlikler öncesinde sonrasına göre daha fazla olduğu görülmektedir. $\mathrm{Bu}$ durum küresel 1sınmanın ozon tabakası ile ilişkilendirilmesiyle açıklanabilir. Kompozisyonlarda etkinlikler öncesinde bu ilişkiden daha fazla bahsedildiği için bu önleme de daha yaygın bir şekilde değinildiği düşünülmektedir. Tablo 6'da verilen bulgular, proje kapsamında yapılan eğitim ve diğer etkinliklerin öğrencileri olumlu yönde etkilediği ve bu konudaki duyarlılıklarının arttığını açık bir şekilde ortaya koymaktadır.

Bunların yanında öğrencilerle yapılan yarı yapılandırılmıș görüşmelerden de iklim değişikliği, küresel ısınma ve bu konularda alınabilecek önlemler ile ilgili olarak öğrencilerin belirli düzeyde kabul edilebilir ölçüde bilgilere sahip olduklarını ortaya koymaktadır. Ancak bütün bunlara rağmen bazı bilgi eksikliklerinin ve hatta bazı yanılgıların da devam ettiği iklim değişikliği farkındalık ölçeğine verilen cevaplardan, yarı yapılandırılmış görüşmelerden ve yazılan kompozisyonlardan anlaşılmaktadır. 
Dikkat çeken en önemli yanlış yukarıda da ifade edildiği gibi iklim değişikliğinin ve küresel ısınmanın ozon tabakasındaki incelme ya da delinme ile açıklanmasıdır. Bu anlayışın öğrenciler arasında yaygın olduğu daha önce yapılan çalışmalarda da vurgulanmaktadır (Pekel, Kaya ve Demir, 2007: 170; Ayvacı ve Çoruhlu, 2009: 11). Benzer şekilde Ratinen ve Uusiautti (2020: 2) yapmış oldukları çalışmada ilkokuldan üniversiteye kadar olan öğrencilerin iklim değişikliğini ozon tabakası ile hatalı bir şekilde bağlamakta oldukları bu nedenle iklim değişikliği eğitimi açısından bu iki kavramın çok benzer oldukları ifade edilmiştir. Avcı vd (2015: 312) yapmış oldukları projeye 6. sınıf, 7. sınıf ve 8. sınıflardan katılan 100 öğrencinin proje sonrası yazdıkları yazılar, yaptıkları resimler incelenmiş ve projedeki etkileşimli uygulamalar ve bilginin görselleştirilmesinin öğrenciler üzerinde olumlu etki bıraktı̆̆ 1 gözlemlenmiştir. Keçeci vd (2019: 60)'nin yürütmüş oldukları projenin sonunda öğrencilerin çevreye yönelik olumlu tutumlar geliştirerek duyarlılıkları artmış ve eskisine oranla çevreye karşı davranışlarında daha hassas olacaklarını belirlemişlerdir. İklim değişikliği ile mücadele edebilmek için bireylerin üzerine düşen görev ve sorumluluklar erken yaşlarda öğretilmesi gerektiği ve iklim değişikliğinin etkilerini azaltmak için ülke genelinde geri dönüşüm uygulamaları arttırılması gerektiği ifade edilmiştir (Atik ve Doğan 2019: 84). Arnon vd. (2015: 1029), İsrail'deki bir devlet kolejinin tüm bölümlerindeki 1147 üniversite öğrencisinin çevresel bilgileri, çevresel değerleri, tutumları ve çevre yanlısı davranışlarıyla ilgili çalışma yürütmüşlerdir. Çalışmada genel çevresel değer ve tutum seviyesinin yüksek olduğunu, ancak çevresel bilgi seviyesinin düşük olduğunu tespit etmişlerdir. Çevre eğitiminin, çevre okuryazarlığııı öğretme ve öğrenme konusunda etkili içeriklere (neye) ve uygulamalara (nasıl) dönüştürülmesi gerektiğini öne sürmüşlerdir.

Çalışma sonucunda elde edilen veriler konu ile ilgili çalışmalara rağmen yanılgıların da devam ettiğini göstermektedir. Öğrencilere yönelik derslerde ya da kaynaklarda bu tarz konular anlatılırken mevcut yanılgılar göz önünde bulundurularak konunun daha anlaşılır bir şekilde ifade edilmesinin faydalı olacağı söylenebilir. Bazı yanılgılara rağmen konu ile ilgili olarak öğrencilerde önemli ölçüde farkındalığın oluştuğu sonucuna ulaşılmıştır. Bu nedenle bu tür çalışmaların sayısının artırılmasının ve farklı seviyelerdeki örneklemler üzerinde yaygınlaştırılmasının gerektiği düşünülmektedir. $\mathrm{Bu}$ çalışmada elde edilen bulgulara dayalı olarak yapılacak çalışmalarda uygulamaya daha fazla ağırlık verilmesinin gerektiği söylenebilir.

\section{Kaynaklar}

Akay, C. (2013). Ortaokul Öğrencilerinin Yaparak-Yaşayarak Öğrenme Temelli TÜBİTAK 4004 Bilim Okulu Projesi Sonrası Bilim Kavramına Yönelik Görüşleri. Mersin Üniversitesi Ĕ̆itim Fakültesi Dergisi, 9(2), 326-338.

Arnon, S., Orion, N. ve Carmi, N. (2015). Environmental literacy components and their promotion by institutions of higher education: An Israeli case study. Environmental Education Research, $21 \quad$ (7), 1029-1055. https://doi.org/10.1080/13504622.2014.966656. 
Atik, A. D. ve Doğan, Y. (2019). Lise Öğrencilerinin Küresel İklim Değişikliği Hakkındaki Görüşleri. Academy Journal of Educational Sciences, 3(1), 84-100

Avcı, E., Özenir, S, Ö., Kurt, M. ve Atik, S. (2015). TÜBİTAK 4004 Doğa Eğitimi ve Bilim Okulları Kapsamında Ortaokul Öğrencilerine Yönelik Gerçekleştirilen “Bizim Deniz Akdeniz" Projesinin Değerlendirilmesi. Amasya Üniversitesi Eğitim Fakültesi Dergisi, 4(2), 312-333.

Ayvacı, H. Ş. ve Çoruhlu, T. Ş., (2009). Öğrencilerin Küresel Çevre Sorunlarına Bakışları ve Kavram Yanılgılarının Belirlenmesine Yönelik Gelişimsel Bir Araştırma. Hasan Ali Yücel Eğitim Fakültesi Dergisi, 12, 11-15.

Başal, H. A. (2015). Okul Öncesi ve İlköğretim Çocukları İçin Uygulamalı Çevre Eğitimi. Nobel Akademi Yayıncılık.

Coyle, K. (2005). Environmental Literacy in America: What Ten Years of NEETF/Roper Research and Related Studies Say about Environmental Literacy in the U.S. The National Environmental Education \& Training Foundation, D.C.

EEA (2020). Sera Gazı Emisyonlarının Azaltımı 14 Eylül 2020 tarihinde https://www.eea.europa.eu/tr/themes/climate/intro Adresinden Edinilmiştir.

Hırça, N. (2013). Üstün Yetenekli Öğrencilerin Yaz Bilim Kampı Deneyimleri. Üstün Yetenekliler Eğitimi Araştırmaları Dergisi, 1(1), 22-30.

González-Gaudiano, E. J., Meira-Cartea, P. A (2019). Environmental education under siege: Climate radicality. The Journal of Environmental Education, Vol. 50, No. 4 $6,386-402$.

IPCC (2021). Working Group I contribution to the Sixth Assessment Report of the Intergovernmental Panel on Climate Change.

Jaaskela, P., Heilala, V., Karkkainen, T., Hakkinen, P. (2021). Student agency analytics: learning analytics as a tool for analysing student agency in higher education. Behaviour and Informatıon Technology, VOL. 40, NO. 8.

Karasar, N. (2006). Bilimsel Araştırma Yöntemi: Kavramlar, İlkeler ve Teknikler. Ankara: Nobel Yayıncılık.

Keçeci, G., Zengin, Kırbağ, F. ve Alan, B. (2019). TÜBİTAK 4004 "Küçük Bilim insanları Elâzı ̆̆ Hazar Gölü Ekosistemini Keşfediyor" Projesinin Ortaokul Öğrencilerinin Çevresel Tutumlarına Etkisi. Insan ve Toplum Bilimleri Araştırmaları Dergisi, 8 (1): 41/63.

Marulcu, D., Saylan, A. ve Güven, E. (2014). 6. ve 7. Sınıf Öğrenciler İçin Gerçekleştirilen "Küçük Bilginler Bilim Okulu'nun” Değerlendirilmesi. Mustafa Kemal Üniversitesi Sosyal Bilimler Enstitüsü Dergisi, 11(25), 341-352. 
MGM (2020). T.C. Tarım ve Orman Bakanlığı Meteoroloji Genel Müdürlüğü. İklim Değişikliği 14 Eylül 2020 tarihinde https://www.mgm.gov.tr/iklim/iklimdegisikligi.aspx Adresinden Edinilmiştir.

Oğurlu, I., Alkan, H., Unal, Y., Ersin, M.O. ve Bayrak, H. (2013). Contributions of Environment and Nature Training to Geography Education: Ide Projects Case Study. The 3rd International Geography Symposium-GEOMED, Kemer-AntalyaTurkey, Symposium Proceedings, ISBN:978-605-62253-8-3.

Pekel, O., Kaya, E. ve Emir, Y. (2007). Farklı Lise Öğrencilerinin Ozon Tabakasına İlişkin Düşüncelerinin Karşılaştırılması. Kastamonu Eğitim Dergisi, 15(1), 169174.

Pfautsch, S. ve Gray,T. (2017). Low factual understanding and high anxiety about climate warming impedes university students to become sustainability stewards An Australian case study. International Journal of Sustainability in Higher Education, Vol. 18 No. 7.

Ratinen, I. ve Uusiautti, S. (2020). Finnish Students' Knowledge of Climate Change Mitigation and Its Connection to Hope. Sustainability, 12, 2181; doi:10.3390/su12062181.

Tekbıyık, A., Şeyihoğlu, A., Sezen Vekli, G. ve Birinci Konur, K. (2013). Aktif Öğrenmeye Dayalı Bir Yaz Bilim Kampının Öğrenciler Üzerindeki Etkilerinin İncelenmesi. The Journal of Academic Social Science Studies, 6(1), 1383-1406.

Tok, G., Cebesoy, B. Ü., Bilican, K. (2017). Sınıf Öğretmeni Adaylarının İklim Değişikliği Farkındalıklarının İncelenmesi. Batı Anadolu Eğitim Bilimleri Dergisi, 8(2), 23-36.

Varela- Candamio, L.V., Novo-Corti, I., García-Alvare, M. T (2018). The importance of environmental education in the determinants ofgreen behavior: A meta-analysis approach. Journal of Cleaner Production, 170, 1565-1578. 